Published by LPMP Imperium

Journal homepage: https://ejournal.imperiuminstitute.org/index.php/AKURASI

\title{
Analisis Pelanggaran Etika Bisnis Terhadap Penayangan Iklan Rokok Di Pertelevisian Indonesia
}

\author{
Sura Klaudia, Kirei Hoshi Fatayo Widyawati, \& Ellyn Citra \\ Putranti \\ STIE Kesuma Negara
}

Financial Management

\begin{abstract}
No single business actor does not advertise their products, be it products made from herbal ingredients, synthetic materials, or even hazardous materials. Advertising itself can be done in various ways, and one way that is currently immensely loved by business people is to advertise their products through television media. Cigarette advertising itself has been considered to have committed several business ethics violations. The purpose of this study was to determine whether there were violations of business ethics that occurred during the broadcast of cigarette advertisements on television. The type of research that will be applied in this research is qualitative research using descriptive qualitative methods. The results showed two kinds of business ethics violations that occurred during the broadcast of cigarette advertisements; the two types of violations were moral violations and empathy violations. Moral violations occur because of the ineffectiveness of limiting cigarette advertisements that the government has set. Meanwhile, the violation of empathy occurs because of a sense of indifference to the cigarette company about the harmful effects that can be caused by smoking behavior on consumer health.

Keywords:

Cigarette Advertising, Business Ethics, Economy
\end{abstract}

Received: 12 Aug 2021

Accepted: 25 Aug 2021

Online: 31 Aug 2021

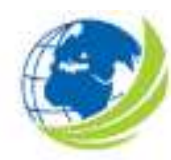

Corresponding Author:

Akurasi: Jurnal Riset

Akuntansi dan Keuangan, Vol 3, No.2, 2021,

pp. $117-126$

eISSN 2685-2888

Sura Klaudia

STIE Kesuma Negara

Jl. Mastrip No. 59, Kepanjen Kidul, Kota Blitar, Jawa Timur 6611

Surel : klaudia@stieken.ac.id

DOI: https://doi.org/10.36407/akurasi.v3i2.486

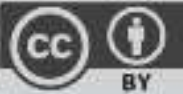

(C) The Author(s) 2021

CC BYThis license allows reusers to distribute, remix, adapt, and build upon the material in any medium or format, so long as attribution is given to the creator. The license allows for commercial use. 


\section{PENDAHULUAN}

Di era serba modern seperti sekarang ini, kegiatan dalam mengiklankan sebuah produk tentunya bukan menjadi suatu perkara yang sulit lagi. Mengingat seberapa berkembang dan majunya dunia pertelekomunikasian di era serba modern seperti sekarang ini. Saat ini, hampir ditiap-tiap rumah paling tidak memiliki satu atau lebih media pendistribusian informasi. Salah satu media pendistribusian informasi yang sangat digemari dan hampir dimiliki oleh seluruh kalangan masyarakat ialah televisi. Televisi dapat diartikan sebagai media pandang sekaligus media pendengar (audio-visual), yang dimana orang tidak hanya memandang gambar yang ditayangkan televisi, tetapi sekaligus mendengar atau mencerna narasi dari gambar tersebut (Ustaahmetoğlu, 2020).

Kepemilikannya yang meluas inilah yang membuat para pelaku usaha berbondongbondong menggunakan televisi sebagai media utama mereka dalam mengiklankan barang atau jasa yang mereka miliki. Periklanan sendiri dapat diartikan sebagai seluruh proses yang meliputi perencanaan, pelaksanaan, pemantauan, umpan balik, maupun penakaran dari sesuatu komunikasi tentang produk dan atau merek (Cheah et al., 2020). Selain karena kepemilikannya yang meluas, televisi juga dipilih karena menurut beberapa penelitian yang telah dilakukan sebelumnya yang menyatakan bahwa televisi dapat menciptakan daya rangsang yang lebih kuat terhadap otak manusia dibandingkan dengan media massa yang lainnya. Hal ini tentunya sangat sejalan dengan tujuan para pelaku usaha dalam membuat suatu iklan yakni untuk mempengaruhi pikiran masyarakat agar mau membeli produk yang mereka miliki (Zhang et al., 2021). Iklan dapat mempengaruhi konsumen melalui beragam metode, namun yang paling utama adalah bahwa tujuan iklan adalah meningkatkan kemungkinan bahwa konsumen yang terpapar iklan akan berperilaku atau percaya seperti yang diinginkan sang pengiklan (Ustaahmetoğlu, 2020). Namun tak jarang ada sebagian pelaku usaha yang berniat untuk menyalahgunakan salah satu keunggulan televisi dalam menciptakan daya rangsang yang lebih kuat terhadap otak manusia ini. Salah satu iklan pertelevisian yang banyak menimbulkan perdebatan dan kontroversi di kalangan masyarakat ialah iklan yang berhubungan dengan rokok. Banyak sekali masyarakat yang memperdebatkan pelanggaran etika dan moral yang terdapat didalam tayangan iklan tersebut (Kunci, 2012).

Tak sedikit masyarakat yang masih berpendapat bahwa tayangan iklan rokok yang selama ini muncul di pertelevisian Indonesia telah melanggar beberapa etika dan norma yang ada di masyarakat, salah satunya ialah jam penayangan iklan yang dianggap masih kurang tepat. Iklan (rokok) di media penyiaran (televisi dan radio) hanya dapat ditayangkan setelah pukul 21.30 sampai dengan pukul 05.00 waktu setempat. Tujuan dari ditentukannya jam penayangan ini ialah agar iklan tidak dapat dilihat maupun didengar oleh anak-anak yang masih di bawah umur (Kertamukti, 2017). Namun, pada kenyataannya jam penayangan iklan rokok ini terkadang masih bertepatan dengan jam bangun anak-anak yang masih di bawah umur, dimana hal ini tentunya menimbulkan keresahan di hati para orang tua dimana kebanyakan orang tua merasa takut bahwa anak mereka yang masih di bawah umur akan ikut-ikutan merokok setelah melihat tayangan iklan tersebut.

\section{KAJIAN PUSTAKA}

\section{Etika Bisnis}

Sebelum mengetahui apa yang dimaksud dengan etika binis kita harus mengetahui terlebih dahulu apa yang dimaksud dengan etika. Kata 'Etika' berasal dari bahasa Yunani'Ethos' (Ta Etha) yang dalam bentuk tunggal memiliki arti, adat istiadat atau kebiasaan. Etika seringkali dikaitkan dengan kebiasaan 
hidup yang baik, baik itu pada diri perseorangan maupun pada suatu kelompok masyarakat tertentu (Ayodele et al., 2020; Sherin Maydiana, 2020). Etika bisa dibilang selalu memiliki keterkaitan yang erat dengan tatacara hidup yang baik, aturan hidup yang baik, nilai-nilai maupun segala kebiasaan yang dianut maupun diwariskan dari satu individu kepada individu yang lainnya ataupun dari satu generasi ke generasi yang lainnya (Aviatri \& Nilasari, 2021). Secara garis besar terdapat 2 jenis teori etika, diantaranya ialah sebagai berikut (Aviatri \& Nilasari, 2021):

\section{Etika Teleologi}

Teleologi diambil dari kata Yunani yakni 'Telosi' yang berarti tujuan. Teleologi sendiri memiliki arti untuk mengukur baik buruknya suatu tindakan berdasarkan jenis tujuan yang ingin dicapai dengan tindakan tersebut, ataupun berdasarkan pada akibat yang akan ditimbulkan oleh adanya tindakan itu.

\section{Teori Deontologi}

Deontologi diambil dari kata Yunani 'Deon' yang berarti tugas dan 'Iogos' yang berarti pengetahuan. Sehingga Etika Deontologi dapat diartikan sebagai menekanikan kewajiban manusia dalam bertindak secara baik dan benar. Suatu tindakan tidak dinilai dan dibenarkan hanya berdasarkan pada akibatnya saja atau tujuan baik dari dolakukannya tindakan tersebut, melainkan berdasarkan pada tindakan itu sendiri. Sebagai contoh : apabila seseorang diberi tugas dan orang tersebut melaksanakannya sesuai dengan tugas yang telah diberikan kepada mereka maka itu akan dianggap sebagai benar, sedangkan akan dikatakan salah apabila seseorang tersebut tidak melaksanakan tugasnya sebagaimana yang telah diberikan kepadanya. Teori deontologi memfokuskan penilaiannya kepada hak-hak yang dimiliki oleh masing-masing individu. Berikut ini adalah tiga tahapan dalam menilai benar tidaknya etika tersebut menurut teori deontologi:

1. Apakah tindakan tersebut akan menguntungkan.

2. Apakah orang akan respect dengan tindakan kita.

3. Apakah manfaat dari tindakan tersebut telah terdistribusikan secara adil/benar.

Bila etika sering dikaitkan dengan kebiasaan hidup yang baik maka bisnis erat kaitannya dengan kegiatan yang bertujuan untuk memperoleh keuntungan. Bisnis dapat didefiniskan sebagai seluruh rangkaian kegiatan yang direncanakan serta dijalankan oleh perorangan ataupun kelompok secara sistematis dengan tujuan untuk mencari keuntungan (Arfiansyah, 2020; Kreitner, 1983). Bisnis dapat diartikan sebagai suatu usaha yang dijalankan dengan tujuan utamanya adalah untuk memperoleh keuntungan (Ramdhaningsih, 2013; Rendtorff, 2019).

Etika dan bisnis sendiri merupakan dua hal yang saling berhubungan antara satu dengan yang lainnya, hubungan diantara keduanya ini disebut sebagai etika bisnis. Etika bisnis adalah sebuah pemikiran atau refleksi kritis mengenai moralitas dalam kegiatan ekonomi dan bisnis (Arfiansyah, 2020; Syamsudin, 2020). Etika bisnis dapat diartikan sebagai sekelompok aturan yang menegaskan sejauh mana suatu bisnis boleh bertindak dan tidak boleh bertindak, dimana aturan-aturan tersebut dapat bersumber dari aturan tertulis maupun aturan yang tidak tertulis, dan apabila suatu bisnis sampai ketahuan melakukan pelanggaran atas aturan-aturan tersebut maka sangsilah yang akan mereka terima, dimana sangsi tersebut dapat berbentuk langsung maupun tidak langsung (Fisher, 2003). Menurut kedua pengertian tersebut dapat ditarik kesimpulan bahwa yang dimaksud dengan etika bisnis ialah sebuah pemikiran atau refleksi kritis mengenai moralitas dalam kegiatan ekonomi dan bisnis baik itu dalam bentuk tertulis maupun tidak tertulis yang apabila dilanggar akan mendapatkan sangsi baik itu secara langsung maupun tidak langsung. 


\section{Pengertian Iklan}

Iklan merupakan sebuah elemen komunikasi pemasaran yang persuasif, nonpersonal, yang dibayar oleh pihak sponsor dan disebarkan melalui saluran komunikasi massa dalam rangka mempromosikan pemakaian barang atau jasa (Riantina Luxiarti \& Syaputra, 2020; Syamsudin, 2020; Zhang et al., 2021). Iklan juga merupakan sebuah media informasi yang dibuat dengan cara tertentu untuk menarik perhatian penonton, asli, dan memiliki karakteristik tertentu dan persuasif, sehingga membuat konsumen secara sukarela terdorong untuk melakukan sesuatu sesuai dengan apa yang diinginkan oleh pengiklan (Cheah et al., 2020; Qudri et al., 2016). Selain pendapat yang telah dikemukakan oleh para ahli, berikut ini adalah beberapa definisi umum mengenai iklan yang sering mampir di pemikiran masyarakat umum (Ustaahmetoğlu, 2020) :

1. Iklan memiliki definisi sebagai berita pesanan yang berguna untuk membujuk maupun mendorong khalayak ramai untuk membeli barang atau jasa yang ditawarkan olehsi pemasang iklan.

2. Iklan juga dapat pula didefinisikan sebagai pemberitahuan kepada khalayak ramai mengenai barang atau jasa yang ingin ditawakan serta dipasang di dalam media massa, seperti majalah, surat kabar/koran, dan media elektronik seperti televisi, radio, dan internet.

Berdasarkan definisi-definisi yang telah disampaikan, dapat disimpulkan bahwa iklan adalah sebuah elemen komunikasi yang dibuat dengan cara tertentu untuk menarik perhatian penonton dan bersifat persuasif yang dibayar oleh pihak sponsor dan disebarkan melalui saluran komunikasi massa dengan tujuan untuk mempromosikan barang atau jasa tertentu serta mendorong ataupun membujuk para penikmat iklan agar memiliki atau memenuhi permintaan dan harapan dari si pemasang iklan.

\section{Tujuan Iklan}

Seperti yang telah kita ketahui bersama bahwa iklan bukanlah satu-satunya media yang dapat digunakan oleh perusahaan untuk memasarkan produk-produknya. Hal ini tentunya berkaitan dengan maksud dari dihadirkannya sebuah iklan. Iklan tidak pernah dimaksudkan untuk memberikan peningkatan penjualan dalam jangka waktu yang panjang. Namun meskipun demikian, iklan tetap menjadi salah satu kegiatan yang efektif dalam mendukung aktivitas-aktivitas pemasaran, sehingga Secara umum tujuan perusahaan dalam mengiklankan produk buatannya ialah untuk (Cheah et al., 2020):

1. Mengkomunikasikan informasi kepada para konsumen mengenai atribut maupun manfaat suatu merek.

2. Menciptakan norma-norma kelompok.

3. Mengembangkan atau merubah citra atau personalitas dari sebuah merek.

4. Mengasosiasikan suatu merek dengan perasaan serta emosi.

5. Mengedepankan perilaku konsumen.

6. Mengarahkan konsumen untuk membeli produknya dan mempertahankan market power perusahaan.

7. Menarik calon konsumen menjadi konsumen yang loyal dalam jangka waktu tertentu.

8. Mengembangkan sikap positif calon konsumen yang diharapkan dapat menjadi pembeli potensial dimasa yang akan datang.

9. Menciptakan sebuah kesadaran pada suatu merek tertentu didalam benak para konsumen. Brand awareness yang tinggi telah menjadi kunci pembuka untuk tercapainya sebuah brand equity yang kuat. 
Pada dasarnya dunia periklanan merupakan dunia komunikasi yang beresensi persuasif (membujuk atau mempengaruhi) (Arfiansyah, 2020). Sehingga dari keseluruhan penjelasan ini tentunya dapat disimpulkan bahwa tujuan akhir dari penyusunan sebuah iklan ialah sebagai rangkaian kegiatan komunikasi untuk menjangkau lapisan masyarakat tertentu, agar mereka dapat membantu dalam memperluas serta menyebarkan informasi serta mempergunakannya dalam jangka waktu yang lama. Para pelaku usaha tentunya menyadari bahwa konsumen bukanlah pribadi yang serta merta dapat diubah secara tiba-tiba dari insan yang tidak tertarik menjadi pembeli yang berkeyakinan. Dalam beberapa kasus, para konsumen selalu melakukan langkah-langkah tertentu sebelum mereka membeli sebuah barang atau jasa. Pada umumnya para konsumen akan bergerak dari keadaan tidak mengetahui informasi maupun detail tentang barang atau jasa yang ada dihadapannya atau dilihatnya menjadi mengetahuinya dan kemudian mengenalinya, menyukainya, memilihnya, lalu menerima juga meyakininya, dan pada akhirnya membeli barang atau jasa yang dimaksud. Langkah-langkah komunikasi persuasif tersebut terlihat bahwa ada 3 (tiga) tujuan utama dari pemasangan iklan yang dimaksud, yaitu (Subroto, 2011) :

1. Membentuk kesadaran pada khalayak untuk mengetahui dan memahami segala sesuatu mengenai barang atau jasa yang ditawarkan;

2. Menciptakan sebuah perasaan yang sedemikian rupa sehingga khalayak dapat menyukai dan memilih barang atau jasa yang telah ditawarkan;

3. Mendorong khalayak untuk berpikir dan bertindak (membeli) serta menggunakan barang atau jasa yang telah ditawarkan.

Tujuan diatas tentunya dapat dicapai secara bertahap dari tujuan yang satu ke tujuan yang berikutnya, sampai dengan tujuan yang terakhir sesuai dengan kegunaan serta fungsi dari barang atau jasa tersebut dalam kehidupan sehari-hari penikmatnya. Apabila sebuah barang atau jasa mulai dipasarkan kepada para konsumen, maka tujuan utama dari pemasangan iklan ialah untuk memberikan informasi secara rinci mengenai barang atau jasa tersebut. Kemudian jika laju pemasarannya semakin pesat, maka tekanan yang ada pada tujuannya pun akan semakin berubah; dimana disini tujuan pemasangan iklan ialah untuk dapat bersaing dengan produk sejenis. Selanjutnya jika pasaran barang atau jasa tersebut masuk ke dalam tahap yang lebih mantap dalam perkembangannya, maka pemasangan iklan pun bisa lebih ditujukan untuk memelihara nama serta merek dari barang atau jasa yang bersangkutan di mata kalangan konsumennya.

\section{Iklan Rokok di Televisi}

Televisi merupakan media periklanan yang terkenal dengan keunggulan dalam daya jangkauanya yang cukup luas, serta tampilan dalam bentuk audio dan visualnya yang sangat memukau. Audio visual sendiri dapat diartikan sebagai "suatu cara untuk menghasilkan atau menyampaikan materi dengan menggunakan mesin-mesin mekanis dan elektronik, untuk menyajikan pesan-pesan audio dan visual" (Kartika et al., 2020; O'Leary \& Polosa, 2020). Karena kemampuan audio visualnya yang sangat memukau inilah yang membuat televisi menjadi media pilihan utama bagi para produsen rokok untuk mempromosikan produk-produk yang mereka miliki. Sebagian besar iklan rokok menggunakan tiga strategi komunikasi kreatif yakni slice or life, story line, dan close-up. Strategi slice or life merupakan strategi yang memanfaatkan penggalan dari kehidupan sehari-hari dalam bersosialisasi dengan masyarakat lain (Fisher, 2003). Strategi story line merupakan strategi yang dipakai untuk membuat semua khalayak ramai, tertarik mengikuti alur cerita dari iklan yang diberikan, yang pada umumnya menarik, seperti penggalan film-film pendek (Kalimah, 2015). Strategi close-up merupakan strategi yang dipakai dalam iklan rokok untuk menunjukkan kejelasan ekspresi dari aktor yang memerankan iklan tersebut (Rendtorff, 2019; Riantina Luxiarti \& Syaputra, 2020). Ketiga strategi komunikasi 
tersebut akan saling mendukung sehingga terciptalah sebuah iklan yang menarik, kreatif, dan sesuai dengan konsumen yang menjadi sasarannya.

Menurut Peraturan Pemerintah Nomor 109 Pasal 1 Tahun 2012 yang mengatur tentang Pengamanan Bahan yang Mengandung Zat Adiktif Berupa Produk Tembakau Bagi Kesehatan yang dimaksud "iklan niaga produk tembakau yang selanjutnya disebut iklan produk tembakau, adalah iklan komersial dengan tujuan memperkenalkan dan/atau memasyarakatkan barang kepada khalayak sasaran untuk mempengaruhi konsumen agar menggunakan produk tembakau yang ditawarkan". Produk tembakau merupakan sebuah produk yang secara sebagian maupun keseluruhan terbuat dari daun tembakau sebagai bahan bakunya yang diolah kemudian digunakan dengan cara dibakar, dihisap dan dihirup ataupun dikunyah. Selain itu, peraturan yang mengatur penyampaian pesan iklan rokok juga telah diatur dalam Peraturan Pemerintah Nomor 109 Tahun 2012 tentang Pengamanan Bahan Yang Mengandung Zat Adiktif Berupa Produk Tembakau Bagi Kesehatan, tayangan iklan rokok di televisi telah dilarang untuk memvisualisasikan wujud dan bungkus rokok serta tidak boleh mengajak khalayak untuk merokok. Selain itu, adapula aturan jam tayang iklan rokok yang dimulai dari pukul 21.30 hingga pukul 05.00 waktu setempat yang cukup menyulitkan bagi para kreator iklan untuk mencari suatu strategi komunikasi yang tepat.

\section{METODE}

Jenis penelitian yang akan diterapkan dalam penelitian ini ialah penelitian kualitatif. Jenis data yang akan digunakan dalam penelitian ini ialah data sekunder. Data sekunder yang akan digunakan dalam penelitian ini berupa buku-buku, jurnal-jurnal, skripsi, tesis, internet serta berbagai literatur yang relevan dengan penelitian ini. Untuk teknik pengumpulan datanya sendiri akan dilakukan dengan menggunakan teknik observasi (pengamatan) dan teknik interview (wawancara). Berikut ini adalah daftar informan yang akan peneliti wawancarai dalam penelitian ini:

Tabel 1.

Daftar informan

\begin{tabular}{lllll}
\hline No & Inisial Nama & Umur & Gender & Pekerjaan \\
\hline $\mathbf{1}$ & HH & 25 Tahun & Laki-laki & Sales \\
$\mathbf{2}$ & ES & 50 Tahun & Perempuan & Ibu Rumah Tangga \\
$\mathbf{3}$ & SW & 49 Tahun & Laki-laki & Wiraswasta \\
\hline
\end{tabular}

\section{HASIL DAN DISKUSI}

\section{Pelanggaran Etika Bisnis}

Pelanggaran dapat diartikan sebagai sebuah perbuatan menyimpang dalam melakukan suatu tindakan tertentu menurut kehendak sendiri dengan tanpa memperhatikan peraturan yang telah dibuat sebelumnya. Sedangkan, menurut Irham Fahmi (2013) etika bisnis dapat diartikan sebagai sekelompok aturan yang menegaskan sejauh mana suatu bisnis boleh bertindak dan tidak boleh bertindak, dimana aturan-aturan tersebut dapat bersumber dari aturan tertulis maupun aturan yang tidak tertulis, dan apabila suatu bisnis sampai ketahuan melakukan pelanggaran atas aturanaturan tersebut maka sangsilah yang akan mereka terima, dimana sangsi tersebut dapat berbentuk langsung maupun tidak langsung. Menurut kedua pengertian tersebut dapat ditarik kesimpulan bahwa yang dimaksud dengan pelanggaran etika bisnis ialah suatu bentuk penyimpangan terhadap aturan-aturan tertulis maupun tidak tertulis yang menjadi pedoman atau 
acuan bagi suatu bisnis dalam bertindak atau dengan kata lain mengoperasikan bisnisnya dengan etik.

\section{Penayangan Iklan Rokok}

Pemerintah telah mengeluarkan beberapa regulasi yang membahas tentang penayangan iklan rokok di pertelevisian Indonesia, salah satunya ialah Peraturan Pemerintah Nomor 109 Tahun 2012 yang mengatur tentang Pengamanan Bahan yang Mengandung Zat Adiktif Berupa Produk Tembakau Bagi Kesehatan. Menurut pasal 1 PP nomor 109 Tahun 2012 yang dimaksud dengan "iklan niaga produk tembakau yang selanjutnya disebut iklan produk tembakau, adalah iklan komersial dengan tujuan memperkenalkan dan/atau memasyarakatkan barang kepada khalayak sasaran untuk mempengaruhi konsumen agar menggunakan produk tembakau yang ditawarkan". Bila pada pasal 1 kita telah diterangkan mengenai apa yang dimaksud dengan iklan produk tembakau maka pada pasal 27 kita akan diterangkan mengenai cara penyampaian pesan iklan rokok yang sesuai dengan aturan pemerintah, dimana di dalam peraturan tersebut telah dijelaskan bahwa tayangan iklan rokok di televisi telah dilarang untuk memvisualisasikan wujud dan bungkus rokok serta tidak boleh mengajak khalayak untuk merokok. Masih dengan peraturan yang sama yakni Peraturan Pemerintah Nomor 109 Tahun 2012 namun kini pada pasal 29 adapula aturan yang mengatur mengenai jam tayang iklan rokok yang dimulai dari pukul 21.30 hingga pukul 05.00 waktu setempat yang tentunya cukup menyulitkan bagi para kreator iklan untuk mencari suatu strategi komunikasi yang tepat.

\section{Pelanggaran Etika Bisnis terhadap Penayangan Iklan Rokok}

Dalam memasarkan produk rokok, terdapat empat permasalahan etika yang menjadi dilematis tersendiri salah satunya ialah etika periklanan. Etika periklanan ialah sebuah etika yang mengatur tentang profesionalis periklanan. Ada beberapa isu yang sering muncul dalam etika penayangan iklan rokok, salah satunya ialah anggapan tentang masih belum efektifnya pembatasan jam tayang iklan rokok. Hal ini sejalan dengan tanggapan yang telah diutarakan oleh ibu ES yang berprofesi sebagai seorang ibu rumah tangga yang kini berusia 50 tahun.

"Menurut saya pembatasan jam tayang iklan rokok ditelevisi yang dimulai pada pukul 21.30 sampai dengan pukul 05.00 sangatlah tidak efektif. Karena anak saya yang masih berusia 13 tahun (masih dibawah umur) terbiasa tidur di atas jam 10 malam dikarenakan sibuk mengerjakan tugas-tugas sekolahnya. Selain itu, pada jam 4 pagi biasanya anak saya sudah bangun untuk bersiap-siap melaksanakan ibadah shalat subuh dan pada jam itu pula biasanya anak saya menonton televisi. Ini artinya anak saya masih bisa menonton tayangan iklan rokok yang ada di televise. Jadi, menurut saya pembatasan jam tayang iklan rokok yang selama ini telah ditetapkan oleh pemerintah sangatlah tidak efektif." (wawancara dengan ibu ES pada hari Jum'at tanggal 04 Juni 2021).

Hal yang disuarakan oleh ibu ES senada dengan apa yang dikemukakan oleh Direktur Eksekutif Lentera Anak Indonesia.

"Pembatasan jam tayang iklan rokok dari 21.30-05.00 tidak efektif. Karena nyatanya lebih dari 90 persen anak-anak melihat iklan rokok di televisi." (Hery Chariansyah, 2013)

Dari kedua pendapat tersebut dapat disimpulkan bahwa tujuan dari ditetapkannya pembatasan jam tayang iklan rokok di televisi yang dimulai pada pukul 21.30 sampai dengan pukul 05.00 belumlah efektif. Dimana pada hakikatnya, pembatasan jam tayang ini dimaksudkan agar iklan 
tidak dilihat maupun didengar oleh anak di bawah umur maupun para remaja, namun pada kenyataannya jam penayangan iklan rokok ini terkadang masih bertepatan dengan jam bangun anak-anak yang masih di bawah umur, dimana hal ini tentunya menimbulkan keresahan di hati para orang tua dimana kebanyakan orang tua merasa takut bahwa anak mereka yang masih di bawah umur akan ikut-ikutan merokok setelah melihat tayangan iklan tersebut. Hal ini tentu saja telah melanggar etika bisnis secara moral, dimana secara tidak langsung iklan rokok dapat menuntun anak-anak untuk masuk ke dalam perilaku merokok yang mana hal ini dapat merusak moral kehidupan anak bangsa.

Isu selanjutnya ialah anggapan tentang sejauh mana iklan bisa dipertanggung jawabkan ketika produk yang ditawarkan merupakan produk yang berbahaya. Hal ini sejalan dengan tanggapan yang telah diutarakan oleh bapak SW yang berprofesi sebagai seorang wiraswasta yang kini berusia 49 tahun.

"Saya pernah berhenti merokok selama beberapa bulan setelah saya mengalami rasa panas, sakit dan sesak pada dada saya. Namun entah mengapa saat saya tak sengaja menonton iklan rokok yang begitu menarik di televisi, saya menjadi berkeinginan untuk kembali merokok. Walaupun setelahnya, dada saya kembali terasa sesak namun saya tidak perduli." (wawancara dengan bapak SW pada hari Jum'at tanggal 04 Juni 2021).

Hal serupa juga disuarakan oleh saudara HH yang berprofesi sebagai seorang sales yang kini berusia 25 tahun.

"Saya adalah seoarang perokok aktif walaupun pada kenyataannya saya memiliki riwayat sesak nafas. Walau terkadang saya mengalami rasa sakit dan sesak pada dada saya namun hal tersebut tak menghentikan saya untuk terus merokok." (wawancara dengan saudara HH pada hari Jum'at tanggal 04 Juni 2021).

Kedua pendapat ini juga didukung oleh pendapat yang diutarakan oleh seorang dokter dalam sebuah laman web kesehatan.

"Kandungan berbahaya yang terdapat pada rokok adalah nikotin, tar, karbon monoksida yang dimana zat-zat tersebut sangat menganggu sistem pernapasan. Untuk itu, alangkah baiknya jika kebiasaan merokok ini segera dihentikan agar tidak terjadi lkerusakan organ di dalam tubuh khususnya jantung dan paru-paru." (Dr. Ester Agustina, 2019)

Dari ketiga pendapat tersebut dapat disimpulkan bahwa tayangan iklan rokok lagi-lagi telah melanggar etika bisnis dalam hal empati. Dalam hal ini, perusahaan rokok dianggap tidak memikirkan sama sekali bagaimana dampak yang akan ditimbulkan dari perilaku merokok terhadap kesehatan konsumen mereka. Iklan rokok yang selama ini tayang di pertelevisian Indonsesia dianggap telah menyebarkan kebohongan akan penggambaran fisik dari seorang perokok aktif. Walaupun pada bagian bawah iklan terdapat peringatan bahwa rokok berbahaya dan dapat membunuh seseorang yang mengkonsumsinya namun dalam beberapa tayangan iklan peringatan itu ditulis dalam rangkaian huruf yang relatif kecil dengan waktu kemunculan yang relatif cepat membuat para penonton termasuk penulis harus menonton iklan selama beberapa kali baru bisa melihat dengan jelas apa yang tertulis pada bagian tersebut.

\section{KESIMPULAN}

Pelanggaran etika bisnis dapat diartikan sebagai suatu bentuk penyimpangan terhadap aturan-aturan tertulis maupun tidak tertulis yang menjadi pedoman atau acuan bagi suatu bisnis dalam bertindak 
atau dengan kata lain mengoperasikan bisnisnya dengan etik. Berdasarkan penelitian yang telah dilakukan, maka dapat ditarik beberapa kesimpulan mengenai pelanggaran etika bisnis yang terjadi selama penayangan iklan rokok di pertelevisian indonesia diantaranya ialah sebagai berikut:

Hasil penelitian menunjukkan bahwa terdapat 2 macam pelanggaran etika bisnis yang terjadi selama penayangan iklan rokok di pertelevisian Indonesia. Kedua jenis pelanggaran tersebut ialah pelanggaran moral dan pelanggaran empati. Pelanggaran moral yang terjadi selama penayangan iklan rokok di pertelevisian Indonesia terlihat dari masih kurang efektifnya pembatasan jam tayang iklan rokok yang telah ditetapkan oleh pemeritah. Pembatasan jam tayang iklan rokok di televisi yang dimulai pada pukul 21.30 sampai dengan pukul 05.00 dinilai belum efektif sebab jam penayangan iklan rokok ini terkadang masih bertepatan dengan jam bangun anak-anak yang masih di bawah umur, dimana secara tidak langsung iklan rokok dapat menuntun anak-anak di bawah umur untuk masuk ke dalam perilaku merokok yang mana hal ini dapat merusak moral kehidupan anak bangsa.

Pelanggaran empati terjadi karena adanya rasa ketidakperdulian pada diri perusahaan rokok terhadap dampak buruk yang dapat ditimbulkan dari adanya perilaku merokok pada kesehatan konsumen. Iklan rokok yang selama ini tayang di pertelevisian Indonsesia dianggap telah menyebarkan kebohongan akan penggambaran fisik dari seorang perokok aktif. Walaupun pada bagian bawah iklan terdapat peringatan bahwa rokok berbahaya dan dapat membunuh seseorang yang mengkonsumsinya namun dalam beberapa tayangan iklan, peringatan itu ditulis dalam rangkaian huruf yang relatif kecil dengan waktu kemunculan yang relatif cepat membuat penonton tidak bisa melihatnya dengan jelas.

\section{REFERENSI}

Arfiansyah, A. (2020). Tinjauan Etika Bisnis Islam dalam Corporate Social Responsibility PT. Garudafood Kabupaten Pati. Jurnal Ilmiah Ekonomi Islam, 6(3), 654. https://doi.org/10.29040/jiei.v6i3.1411

Aviatri, P., \& Nilasari, A. P. (2021). Analisis Penerapan Etika Bisnis Terhadap Kelangsungan Usaha Perusahaan Dagang. ACCOUNTHINK: Journal of Accounting and Finance, 6(02), 194-205. https://journal.unsika.ac.id/index.php/accounthink/article/view/5621

Ayodele, T. O., Oladokun, T. T., \& Kajimo-Shakantu, K. (2020). Employability skills of real estate graduates in Nigeria: a skill gap analysis. Journal of Facilities Management, 18(3), 297-323. https://doi.org/10.1108/JFM-04-2020-0027

Cheah, I., Teah, M., Lee, S., \& Davies, Z. (2020). Straight eye for the queer ad: attitudes, skepticism, inferences of manipulative intent and willingness to buy. Asia Pacific Journal of Marketing and Logistics, 33(5), 1220-1238. https://doi.org/10.1108/APJML-03-2020-0124

Fisher, J. (2003). Surface and deep approaches to business ethics. Leadership \& Organization Development Journal, 24(2), 96-101. https://doi.org/10.1108/01437730310463288

Kalimah, S. (2015). Pertanggungjawaban Sosial Pabrik Rokok Alaina Ditinjau Dari Etika Bisnis Islam. An-Nisbah: Jurnal Ekonomi Syariah, 2(1). https://doi.org/10.21274/an.2015.2.1.349378

Kartika, M. H., Hukum, I., Hukum, F., Islam, U., Agung, S., Fakultas, D., Universitas, H., \& Sultan, I. (2020). Tanggung Jawab Media Elektronik ( Televisi) Terhadap Kerugian Konsumen Atas ( Television ) Against Consumer Damages for Violation of Cigarette Ad Serving. 213-229.

Kertamukti, R. (2017). Komunikasi Visual Iklan Cetak Rokok di Indonesia Kurun Waktu 1950 2000. Jurnal ASPIKOM, 1(1), 91. https://doi.org/10.24329/aspikom.v1i1.10

Kreitner, R. (1983). Needed: Formal Instruction in Business Ethics for Managers. Journal of Management Development, 2(2), 16-25. https://doi.org/10.1108/eb060113 
O'Leary, R., \& Polosa, R. (2020). Tobacco harm reduction in the 21st century. Drugs and Alcohol Today, 20(3), 219-234. https://doi.org/10.1108/DAT-02-2020-0007

Qudri, A., Gani, I. A., \& Hasyim, S. (2016). Tanggung Jawab Pemerintah Terhadap Iklan Rokok Yang Merugikan Konsumen Dalam Sistem Hukum Positif. Pascasarjana Universitas Syiah Kuala, $4(4)$, http://download.garuda.ristekdikti.go.id/article.php?article=550262\&val=9186\&title=TA NGGUNG JAWAB PEMERINTAH TERHADAP IKLAN ROKOK YANG MERUGIKAN KONSUMEN DALAM SISTEM HUKUM POSITIF

Rendtorff, J. D. (2019). Sustainability and Business Ethics in a Global Society. Philosophy of Management and Sustainability: Rethinking Business Ethics and Social Responsibility in Sustainable Development, 19-28. https://doi.org/10.1108/978-1-78973-453-920191002

Riantina Luxiarti, \& Syaputra, E. M. (2020). Hubungan antara Sikap Pedagang Tentang Etika Promosi Terhadap Niat dan Perilaku Penjualan Rokok. Afiasi : Jurnal Kesehatan Masyarakat, 5(2), 69-74. https://doi.org/10.31943/afiasi.v5i2.105

Sherin Maydiana, H. C. (2020). Etika Bisnis Islam Dalam Era Bisnis Kekinian (Studi Kasus Kedai Kopi Diskuupi Surabaya). Jurnal Ekonomika Dan Bisnis Islam, 3, 110-121.

Subroto, S. (2011). Etika periklanan.

Syamsudin, M. (2020). Tanggungjawab Hukum Pelaku Usaha Periklanan Atas Produk Iklan Yang Melanggar Etika Periklanan (Kajian Kritis Terhadap Uu Perlindungan Konsumen). https://repository.unikom.ac.id/id/eprint/66463

Ustaahmetoğlu, E. (2020). The influence of different advertisement messages and levels of religiosity on attitude and purchase intention. International Journal of Islamic and Middle Eastern Finance and Management, 13(2), 339-356. https://doi.org/10.1108/IMEFM-022019-0064

Zhang, S., Wakefield, R., Huang, J., \& Li, X. (2021). Exploring determinants of consumers' attitudes toward real-time bidding (RTB) advertising. Information Technology and People, 34(2), 496525. https://doi.org/10.1108/ITP-09-2019-0480

\section{DECLARATIONS}

\section{Funding}

The authors received no financial support for the research and publication of this article.

\section{Conflicts of interest/ Competing interests:}

The authors have no conflicts of interest to declare that are relevant to the content of this article.

\section{Data, Materials and/or Code Availability:}

Data sharing is not applicable to this article as no new data were created or analyzed in this study.

\section{How to cite this Article}

Klaudia, S., Fatayo Widyawati, K., \& Putranti, E. (2022). ANALISIS PELANGGARAN ETIKA BISNIS TERHADAP PENAYANGAN IKLAN ROKOK DI PERTELEVISIAN INDONESIA. AKURASI: Jurnal Riset Akuntansi Dan Keuangan, 3(2), 117 - 126. https://doi.org/10.36407/akurasi.v3i2.486 